patient can afford the planned regimen. The usual approach is to state that there is no scientific evidence for or against such treatments.

It is possible that patients with non-specific rheumatic pains in whom no diagnosis is made may resort, in desperation, to alternative medicine more frequently and account for the quoted statistics of extensive expenditure. ${ }^{1-3}$ We do not have immediate access to such a patient population and cannot, therefore, make any meaningful comments. Extension of the study by collaboration with family doctors to include such a population is planned.

We asked about all expenses incurred because of arthritis since we wished to view alternative medicine expenditure in the context of the overall financial implications of rheumatoid arthritis. The total amount spent on aids was surprisingly large and it is striking that by far the greatest benefit was gained from these aids for the home with prescribed medicine a poor second. It is, perhaps, a little disheartening for the rheumatologist that the number of patients who thought that they gained benefit from second-line treatment was no different from those receiving only first-line treatment. Presumably, however, the latter had less severe disease at the outset.

When patients were given the chance to "vote with their purses" they clearly opted for home aids. This is despite the fact that the Centre for Rheumatic Diseases, which fulfils a regional role and serves a population of 2.8 million, has only one part-time occupational therapist and Glasgow has no aids centre. The satisfaction with aids was even more surprising since a survey conducted in Leeds ${ }^{4}$ suggested that many patients were not entirely satisfied with aids purchased. In that study, however, only aids were assessed and the emphasis of questioning was different. The Leeds group was looking for complete satisfaction whereas we were assessing relative benefits, and even a "lot of benefit" does not imply perfection.

It is possible that the expectations of patients with rheumatoid arthritis are more realistic with respect to consumer durables such as potato peelers, showers, raised toilet seats, and washing machines than they are about "miracle" drugs or treatments, where the popular press often misrepresents the facts. It has been shown previously that expectations are important regarding final outcome. ${ }^{5}$ Optimism is important in chronic "incurable" disorders but needs to be tempered with realism; unsubstantiated reports might induce false hope and subsequent disappointment.

Until a truly dramatic solution is found for the disability caused by rheumatoid arthritis, the provision of practical aids to daily living seems worthy of emphasis to patients, their relatives, and those concerned in their care.

\section{References}

1 Arthritis Foundation. Annual report 1975. London: Arthritis Foundation 1975.

2 Decker JL. The final common pathway. Arthritis Rheum 1973;16:765-70.

${ }^{3}$ Rosie G. Can this be relieved by a mussel ? The Scotsman Magazine 1981; 2, No 10:6-10.

4 Chamberlain MA, Stowe J. A survey of personal aids supplied by post to arthritics. Rheumatol Rehabil 1980;19:246-51.

5 Burton KE, Wright V, Richards J. Patients' expectations in relation to outcome of total hip replacement surgery. Ann Rheum Dis 1979;38:471-4.

(Accepted 5 September 1982)

\title{
Family Medicine
}

\section{Thamesmead: lessons learnt}

\author{
P M HIGGINS
}

Our first priority as general practitioners in Thamesmead in 1968 was to establish the practice on the best possible footing, but we had also to consider our future responsibilities for teaching students. General practice was a new academic discipline, and I had no recent experience of teaching students. I had much to learn about my work as a general practitioner and about teaching. At that time a voluntary attachment was the only experience of general practice offered to students at Guy's Hospital Medical School, and about one in 10 students took advantage of it. I visited all the practices near Guy's, and a few allowed us to take students to talk with patients in their homes or at the practice premises each week; we also taught in the medical outpatients department.

Vocational training for general practice was on the way, and practices and general practitioners who were prepared for training would also be prepared for students. What I learnt

Guy's Hospital Medical School, London SE1 9RT

P M HIGGINS, FRCP, FRCGP, Bernard Sunley professor of general practice about training would help with teaching students. In 1969 I became secretary and later chairman of the education committee of the South-east England Faculty of the Royal College of General Practitioners, which had compiled a register of doctors who were willing to take students; this was updated and extended. Plans were well advanced for the region's first training scheme at Cuckfield and proposals for Thanet and for Tunbridge Wells were under negotiation. The general practice research unit at Guy's became the department of general practice in 1969. In 1970 I was appointed regional adviser in general practice and launched London's first course for teachers in general practice. For five years I was tutor to this three-term course, which continues in a shortened form. In 1974 the Bernard Sunley Foundation generously offered Guy's a yearly sum of money, initially for 10 years, to establish a chair of general practice. All the general practitioners in Thamesmead have part-time appointments in the department's undergraduate section and thus make up its teaching staff. The department also has a postgraduate section funded by the Postgraduate Medical Federation. There are now four associate advisers in post; one has a special responsibility for continuing education in inner London, another for research and audit, and a third for trainers and course organisers. 


\section{Teaching}

The undergraduate teaching programme also expanded rapidly after a hesitant start. With pressure from Guy's Student Education Committee two weeks were set aside in 1970 for a voluntary attachment to GPs near Guy's and in the region. Virtually all students took advantage of this with great enthusiasm. ${ }^{1}$ Four years later the curriculum at Guy's underwent a major upheaval. Clinical studies were integrated with preclinical work, sociology and psychology were introduced, and general practice was allotted four weeks in a new joint firm with psychiatry in the fourth year. The attachment continued as part of a new regional firm, based on five regional hospitals. General practice now makes a contribution in three of the five years of the course (table).

Teaching students from Guy's in general practice

\begin{tabular}{|c|c|c|c|}
\hline & Thamesmead & Guy's & Other \\
\hline $\begin{array}{l}\text { First year: } \\
\text { Spring term }\end{array}$ & Talking with patients & & \\
\hline $\begin{array}{l}\text { Second year: } \\
\text { Spring term } \\
\text { Summer term }\end{array}$ & $\begin{array}{l}\text { Interview practice } \\
\text { Interview practice }\end{array}$ & $\begin{array}{l}\text { Problem solving in } \\
\text { general practice }\end{array}$ & \\
\hline $\begin{array}{l}\text { Fourth year: } \\
\text { Psychiatry/GP } \\
\text { Paediatrics }\end{array}$ & $\begin{array}{l}\text { Clinical work } \\
\text { Optional } 2 \text { weeks' }\end{array}$ & Seminars & \\
\hline $\begin{array}{l}\text { Mixed firm* } \\
\text { Regional }\end{array}$ & & Seminars & $\begin{array}{l}2 \text { Weeks in regional } \\
\text { general practice }\end{array}$ \\
\hline
\end{tabular}

-Urology/dermatology/community medicine/general practice.

In the second term students come to Thamesmead to talk with people who have problems, to learn about how their lives have been affected, how they manage, and how doctors have helped or failed them. The first interview a student conducts with a "patient" is at Thamesmead during the second year." These sessions have two unusual features: the "patient" in each case is someone who is under treatment and presents a problem that is worrying or has worried him-the choice is left to him; the "patient" also takes an active part in the teaching. General practice is part of four of the five firms during the fourth year. We aim at giving students clinical responsibility under supervision and the opportunity to see patients on their own. During his time with us each student is in effect the "doctor" of first contact seeing patients (with their consent) who are booked for his tutor. Neither health centre has space to spare for teaching, and we therefore limit the number of students to three each week. We also take trainees from local training schemes and now have two young doctors from Egypt working with us. They will be the first trained academic staff in a new department of general practice in Egypt.

In 1974 a Social Work Training Unit was established after negotiations between Kent University, who were looking for places in health centres for their students, Bexley social services department, and the doctors at Lakeside Health Centre. Students work in the local schools and community organisations, and three of them are now at Lakeside and work closely with the medical team. Medical students work with social work students, and the recent appointment of a second teacher of social work will provide more opportunities for this.

\section{Lessons learnt}

Here I present my views. They are necessarily biased and incomplete. There have been some successes and many failures. We must first acknowledge what an ambitious venture this was - to develop a comprehensive health service emphasising primary care for a large number of people in London and to provide a teaching unit in the community. Those who began it did not foresee all the difficulties-how could they? The combination of problems to be tackled was without precedent.
The challenge was to develop at the same time a series of new group practices, new relationships between services, and teaching in a new discipline. All this was accomplished despite a heavy work load, difficulties in recruiting doctors, lack of supporting staff, and a heavy commitment to planning and administration.

What might have happened without the initiative from John Butterfield and Robert Smith at Guy's Hospital Medical School ? That in itself was an event without precedent-or imitation. No other department of medicine in any London medical school had involved itself so intimately in the problems of community care, and none has done so since. The project was an example of how an academic unit can make good use of its licence to experiment: a model of fruitful collaboration between a medical school and health authorities willing to do new things but constrained by existing boundaries. Apart from Harlow, the first batch of postwar new towns failed dismally to seize opportunities to plan their health services. ${ }^{3}$ In the light of this general failure it is reasonable to feel despondent about what might have happened at Thamesmead. The Greater London Council had no power to act and lacked the knowledge needed to do so; the local boroughs had no experience of and no enthusiasm for health centres. The pattern of services might well have been one of separate clinics and general practitioners working in isolation from each other and from other services. New communities are known to have special problems and make heavy demands on medical services, and London is less attractive to most doctors than other places.

The involvement of Guy's put the whole project onto a different footing. People of goodwill came together from many services. Thamesmead offered an opportunity to change the character of the community's medical services and to improve their standards. The Joint Health Services Advisory Committee (JHSAC) worked well; a structure for planning was introduced, centres were designed and built, services were provided when they were needed, experienced medical and dental staff were recruited, teaching in the community began, new relationships between services developed. In all of these respects things went more smoothly in the bad old days of the tripartite Health Service than they do today. The reorganised, integrated Health Service has still to demonstrate the same capacity for thinking comprehensively about its task and the same flexibility and interest in change.

The JHSAC, was a compromise between no planning at all and full control of health care planning. This had its limitations. Most attention was concentrated on building; the need was urgent and a plan could be agreed without much difficulty. Less attention was given to the special needs of the people of Thamesmead and to developing services to meet them. Planning in the National Health Service revolved largely around buildings, the philosophy being that if buildings were there co-operation would develop among services. Staffing was the responsibility of the existing authorities, which had other commitments. And the curious result was that the agencies and individuals who were most committed to the project were those who are generally thought to lie uneasily out of reach of the National Health Service's planning system. The family practitioner (formerly executive council) services, and later the local consultants, showed the most flexibility and commitment, and the organised hierarchical services of the Health Service and of the local authorities showed the least flexibility. Naturally, we believe that they have been unadventurous and have taken too little heed of the special needs of our community. A particular disappointment has been the failure of the nursing services to rise to the challenge of our community, but I do not despair that they may do so.

The key to the whole medical plan was to develop group practices of good standard, and it is a serious criticism of the JHSAC, of its constituent bodies, and of the mechanisms available in the NHS that not enough room was left to let this happen without undue stress. The slow growth of the poputation of Thamesmead and the limitations of the " $D$ " allowance put the whole venture at risk. A salaried service was, I discovered, 
politically unthinkable, but if there had been another year's delay our practice might not have survived. We had some help and time lessened the harm, but we were-and still are-trying to do too much with too little. Because of this and because of the decision to keep the first group practice fairly conventional, we also have been less adventurous than I had hoped. A more important reason perhaps is that we changed and our interests changed. As virtually the only service with an open door in the early years of Thamesmead we learnt a great deal about the social stresses and reactions of people on our list, and our attention has been focused more and more on individuals and families in difficulties. I believe (though I have no proof) that this has been helpful to the community, but it is very demanding and time consuming work.

One of the purposes of this project was to provide opportunities for students to learn in the community, and I am sure that the project has had a great effect upon the course at Guy's. Two features of Thamesmead are that it is "visible"-it is as recognisable an entity as is a hospital-and that it has grown steadily over the years. Thus when Guy's changed its curriculum in 1974 Thamesmead could not be ignored, and from that date the medical school has had a varied programme of teaching in general practice. We collaborate closely in teaching with the units of psychology and sociology, and there are links with other departments, particularly psychiatry and paediatrics. We are expanding our opportunities to work and to teach with colleagues in social work. There is no residential accommodation, but despite the problems of travelling students seem to be pleased with what we offer, though only one has so far burst into poetry about it. The sessions at Thamesmead in different parts of the general practice course are generally rated highly and much of the pressure for change in favour of general practice has come from students. I have never believed that Thamesmead could or should provide all the teaching in general practice, and we hope to create more teaching opportunities in practices near Guy's in the future.

These seem to me to be important gains, but the project has not achieved all its aims-implicit or explicit. Some indeed are no longer achievable. They were conceived at a time when there was a generally buoyant feeling about the power of medicine. What seemed to be required was to bring to the community and its problems the knowledge, skills, techniques, and ways of looking at things that had been so successful in hospital practice. New machines promised to provide complex biochemical profiles in large numbers. The remote causes of diseases could be established and remedied. Much of this type of thinking has changed. We are no longer so confident about the value of screening or about the results of medical intervention. We recognise that intervention itself has an effect-that it is not a neutral event. There is more awareness of the subtle interaction of social and psychological factors and health and care seeking.
There is more recognition that many of our concepts of disease lack definition and that the evidence on which we base them is subjective.

There have been disappointments a-plenty, of course. The polytechnic, whose scientific departments would have been of great value, will not now move to a site beside the main centre. On this and other lost causes many hours have been spent. The demise of the JHSAC left a planning vacuum that has not been filled. Our hopes that spending more time with patients would reduce utilisation of the health services has still to be fulfilled. The child community services uneasily keep their distance from us, though we are working on the problem. The dental school muffed its chance.

Rewards there are a-plenty also. The two health centres are good places in which to work. We can offer people more than before, and though sometimes the pressure is overwhelming we would not have it otherwise. We are grateful for the help our visiting consultants so willingly give us. Our patients make students welcome. We are fortunate in our good relationships with colleagues of other disciplines and have learnt a great deal from them. And though there is no longer a formal medical project, the sense of being part of a worthwhile enterprise endures, and all who work at Thamesmead share in it.

It is impossible to acknowledge by name all those who have contributed to the Thamesmead project: people in the health service, in the medical school at Guy's, in the Department of Health and Social Security, in the Greater London Council, architects, and others. I should like to pay tribute to the imagination and foresight of the clerks of the two executive councils, Mr F E Miles and Mr L S Willis, and of the secretaries of their two local medical committees, Dr A Talbot Rogers and Dr Dennis Cook, and to Dr James Fairley of the South-east Metropolitan Regional Board who made Thamesmead his personal concern.

I have received from officers of the GLC and of the local boroughs and others much kindness and help. The first chairman of the Greenwich/Bexley Area Health Authority, Mr Jack Hawkins, took a great interest in our work. I am grateful to my colleagues at Thamesmead and at Guy's for their support. I thank Professor J A D Anderson for helpful comments on this paper, and Michael Curwen for help in preparing it; his contribution to the project since its beginnings has been invaluable.

\section{References}

1 Higgins PM. Teaching in general practice. Guy's Hospital Gazette 1973; $89: 64$.

${ }^{2}$ Armstrong D, Hicks BH, Higgins PM, Weinman J. Teaching communication skills to medical students: a general practice based approach. Med Educ 1979;13:82-5.

${ }^{3}$ Dillane JB. Reports from General Practice IV. London: College of General Practitioners, 1966.

(Accepted 14 September 1982)
Do congenital melanocytic naevi carry a high risk of malignant change and should these be removed?

Although usually called birthmarks, most pigmented naevi are not present at birth and new ones may continue to arise well into adult life. Less than $0 \cdot 1 \%$ of all pigmented naevi are truly congenital. ${ }^{12}$ These congenital naevi, however, may assume great importance because they may be large, even meriting the term giant, may be hairy, and, as well as posing a major cosmetic problem, they have a reputation for developing malignant change. Undoubtedly the giant hairy pigmented naevi can undergo malignant change and are responsible for about half of all the albeit rare melanomas of childhood. How often malignant change has been reported as occurring has ranged from 0 to $42 \%$ with $15 \%$ as a reasonable figure. ${ }^{1}$ Giant lesions with irregular pigmentation are particularly suspect. The figure of $15 \%$, however, cannot be extrapolated to the commoner smaller pigmented lesions, and there is little hard evidence that such lesions pose an appreciable risk or a risk any greater than with naevi of later onset. No firm rules can therefore be laid down that all such lesions need to be removed. The individual decision must be based on the potentiality for malignant change, the cosmetic disability caused by the lesion, and the feasibility of surgical removal. In general the larger and more formidable the lesion the greater the indication for surgery, which in itself can be formidable. Currently, there is great interest in the possibility of treating giant hairy pigmented naevi within the first few weeks of life (later in childhood is too late) by the relatively simple technique of dermabrasion or by comparable techniques. ${ }^{3}-\mathbf{R}$ H CHAMPION, consultant dermatologist, Cambridge.

\footnotetext{
' Kopf AW, Bart RS, Rodriguez-Sains RS. Malignant melanoma: a review. $\mathcal{f}$ Dermatol Surg Oncol 1977;3:41-125.

- Castella EE, Grace Dutia M da, Orioti-Parreiras IM. Epidemiology of congenita pigmented naevi. I. Incidence rates and relative frequencies. $\operatorname{Br} \mathcal{F}$ Dermato

$1981 ; 104: 307-15$.
Johnson HA. Permanent removal of pigmentation from giant hairy naevi by dermabrasion in early life. Br f Plast Surg 1977;80:321-3.
} 